\title{
Zingiber officinale Var. Rubrum Extract Increases the Cytotoxic Activity of 5-Fluorouracil in Colon Adenocarcinoma Widr Cells
}

\author{
Sarmoko $^{1 *}$, Iin Solihatii ${ }^{1}$, Joko Setyono ${ }^{2}$, Heny Ekowati ${ }^{1}$, Arif Fadlan ${ }^{3}$
}

1. Department of Pharmacy, Faculty of Health Sciences, Jenderal Soedirman University, Jl. Dr. Soeparno, Karangwangkal, Purwokerto, Central Java, Indonesia, 53123

2. Laboratory of Biochemistry, Faculty of Medicine, Jenderal Soedirman University, Jl. Gumbreg No 1 Purwokerto, Central Java, Indonesia, 53146

3. Department of Chemistry, Faculty of Science and Data Analytics, Institut Teknologi Sepuluh Nopember, East Java, Indonesia

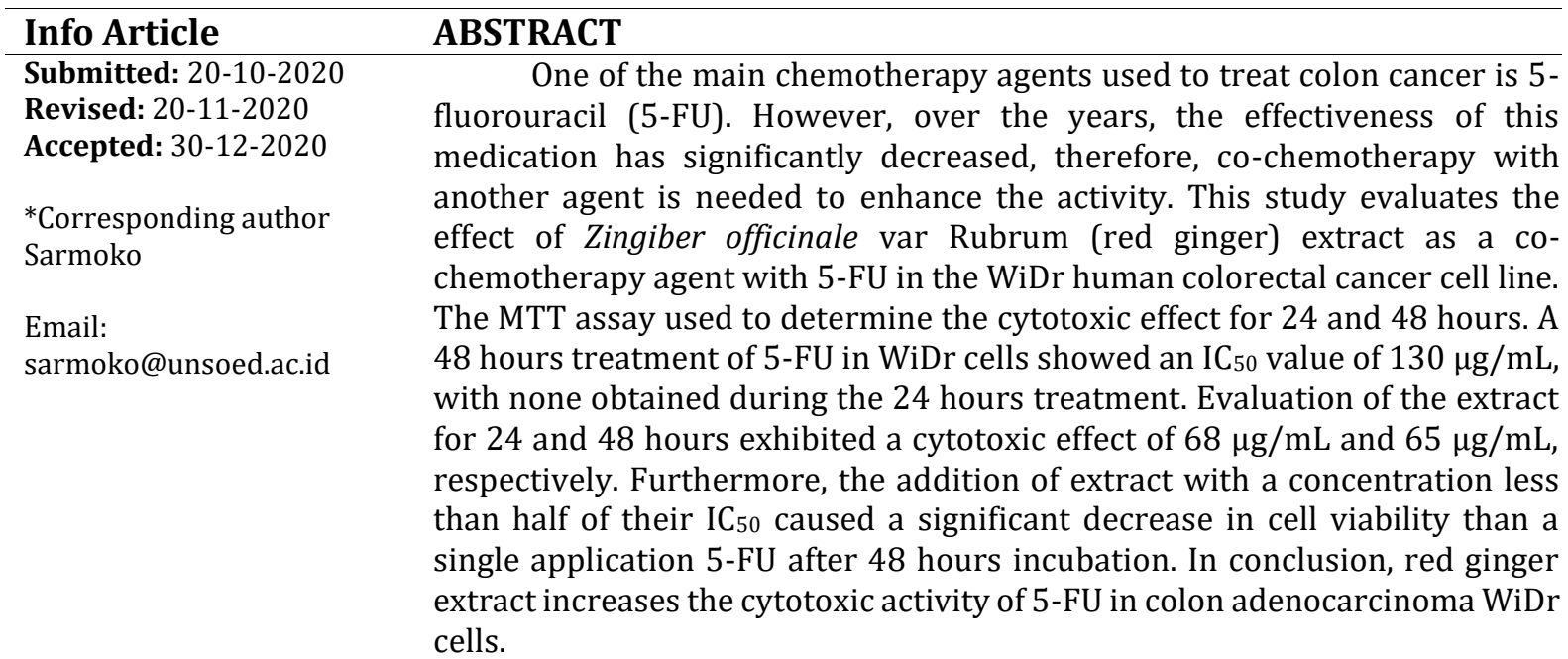

Keywords: Zingiber officinale var Rubrum, 5-Fluorouracil, WiDr cell lines, chemotherapy, cytotoxic effect

\section{INTRODUCTION}

In 2018, colorectal cancer was the third most common cancer type in men and the second in women worldwide. According to Ferlay et al. (2019), the prevalence of colorectal cancer in Indonesia ranks second after breast cancer. One of the main chemotherapy agents for colorectal cancer is 5-fluorouracil (5-FU), with high selectivity on the thymidylate synthetase (Longley et al., 2003). However, the effectiveness of 5-FU as a single chemotherapy agent has only reached $15 \%$. Therefore, the development of additional agents is needed to increase efficacy. Several chemotherapy agents, such as leucovorin, oxaliplatin, and irinotecan, have been combined with 5-FU to enhance its efficiency (Meyerhardt et al., 2005). Unfortunately, these combinations had adverse effects, such as drug resistance and toxicity at high doses (Saif et al., 2009).

A more recent approach in overcoming the above problems is the combination of chemotherapy agents with natural product secondary metabolites. This combination increases metabolic activities in low-dose drugs. Over the past few years, numerous studies have been conducted using natural ingredients combined with 5-FU (Hakim et al., 2014; Nurulita et al., 2011; Nur et al., 2011). The natural ingredients studied and known to have anti-cancer activity are red ginger (Zingiber officinale cv. Rubrum).

Ginger is one of the herbs widely used in traditional medicine. According to Wahyuni et al. (2003), there are three varieties of ginger in Indonesia, namely big ("elephant") ginger ( $Z$. officinale var. Roscoe), small ("emprit") ginger ( $Z$. officinale var. Amarum), and red ginger ( $Z$. officinale var. Rubrum). Red ginger has smaller rhizomes and a spicier taste due to differences in the content of chemical compounds compared to the other two varieties. It contains 6-gingerol and 6-shogaol compounds known to possess anticancer effects (Li et al., 2015; Wu et al., 2015; 
Hwang et al., 2015; Kim et al., 2015; Prasad et al., 2015; Hsu et al., 2015; Han et al., 2015; Fan et al., 2015; Radhakrishnan et al., 2014; Pan et al., 2008). Studies have shown that combining chemotherapy agents with natural ingredients is one of the promising approaches to overcoming cancer treatment problems. Natural ingredients have been used in traditional medicine with anti-cancer activity. In this study, a combination of 5-FU and red ginger was tested on WiDr colon cancer cells to evaluate the potency of red ginger as cochemoterapeutic agent.

\section{MATERIAL AND METHODS}

Z. Officinale var Rubrum was obtained in powdery form from Merapi Farma Herbal (Hargobinangun, Pakem, Sleman, Yogyakarta). The plant authentication was carried out at the Plant Taxonomy Laboratory, Faculty of Biology, Jenderal Soedirman University confirmed that the plant is Zingiber officinale var. Rubrum, and belongs to the family Zingiberaceae.

\section{Extracts preparation}

A total of 1380 grams of the powder was extracted using 4 liters of $96 \%$ ethanol for $4 \times 24$ hours. The filtrate was filtered once a day and evaporated at $80 \mathrm{rpm}, 80^{\circ} \mathrm{C}$ to obtain a thick solvent-free extract with a yield percentage of $7.7 \%$, which is less than $6.6 \%$ according to the provisions of the Indonesian Herbal Pharmacopoeia.

\section{Cell culture}

WiDr colon cancer cells were obtained from the Laboratory of Parasitology, Gadjah Mada University, Yogyakarta, Indonesia. They were grown in RPMI 1640 media (Gibco) supplemented with $10 \%$ fetal bovine serum (Gibco) and $1 \%$ penicillin-streptomycin (Gibco).

\section{Determination of cytotoxicity}

Cytotoxicity of the extract and 5-FU was evaluated by MTT assay. The stock solution $(5 \mathrm{mg} / \mathrm{mL})$ of the extract was prepared in DMSO (Sigma), while the concentration of 5-FU used in the combination test ranged from $30-1000 \mu \mathrm{g} / \mathrm{mL}$. WiDr cells were harvested using $0.25 \% \mathrm{v} / \mathrm{v}$ trypsin-EDTA (Gibco) and were grown to 96-bottom wells (Iwaki) with a density of 10,000 cells per $100 \mu \mathrm{L}$ culture medium, then incubated at $37^{\circ} \mathrm{C}$, using $5 \% \mathrm{CO}_{2}$. Cells were treated with extract concentrations of $15-500 \mu \mathrm{g} / \mathrm{mL}$ for 24 and 48h. After incubation, $100 \mu \mathrm{L}$ MTT (3-(4,5- dimethylthiazol-2-yl)-2,5-diphenyltetrazolium bromide (Sigma) ( $5 \mathrm{mg} / \mathrm{mL}$ in PBS) was added to each well and further incubated for 3 hours. The formed formazan crystals were dissolved in $100 \mu \mathrm{L}$ stopper sodium dodecyl sulfate (SDS) $10 \%$ in $0.01 \mathrm{~N}$ $\mathrm{HCl}$ (Sigma). Absorbance was measured by spectrophotometer at a wavelength of $595 \mathrm{~nm}$ (Biorad) with the cell viability calculated using the following formula \% viability = (absorbance of treatment - absorbance of media)/(absorbance of control - absorbance of media) x 100\%.

\section{The combined treatment of red ginger extract and 5-FU}

The $\mathrm{IC}_{50}$ value of the extract and 5 -FU were first examined, followed by the combination of 5FU and the extract at a concentration of less than half of their $\mathrm{IC}_{50}$ value in 24 and $48 \mathrm{~h}$. The absorbance was obtained from the cochemotherapy test by MTT assay, then the cell viability was calculated.

\section{Data analysis}

Cell viability data were presented as means \pm standard deviation (SD). GraphPad Prism 8.0 (San Diego, CA, USA) was used to generate graphs. Data were analyzed using ANOVA, with the Tukey's range test used to determine the statistical significance. Furthermore, a value of $\mathrm{p}<0.05$ was considered statistically significant.

\section{RESULTS AND DISCUSSION \\ Extract of $Z$. officinale var Rubrum inhibits the growth of WiDr colon cancer cells}

Cytotoxicity was evaluated to determine $Z$. officinale var Rubrum extract's potential to inhibit the growth of WiDr colon cancer cells. The results indicated that the treatment of WiDr colon cancer cells with the extract inhibiting the growth (Figure 1). Furthermore, cell viability obtained from 24 and $48 \mathrm{~h}$ incubation of WiDr cells decreased with the increase in the extract's concentration (Figure 2). Treatment of WiDr cells with the extract at a concentration of $125 \mu \mathrm{g} / \mathrm{mL}$ for 24 and $48 \mathrm{~h}$ incubation inhibited cell growth close to $100 \%$. The cytotoxicity evaluation of the extract showed that the $\mathrm{IC}_{50}$ value at 24 and $48 \mathrm{~h}$ incubation was 68 and $65 \mu \mathrm{g} / \mathrm{mL}$, respectively.

\section{5-FU decreases cell viability of WiDr colon cancer cell \\ Figure 3 shows that the cytotoxicity test of 5 -FU in WiDr cells at 24 and 48 incubation hours decreased in cell viability with an increase in 5-FU}



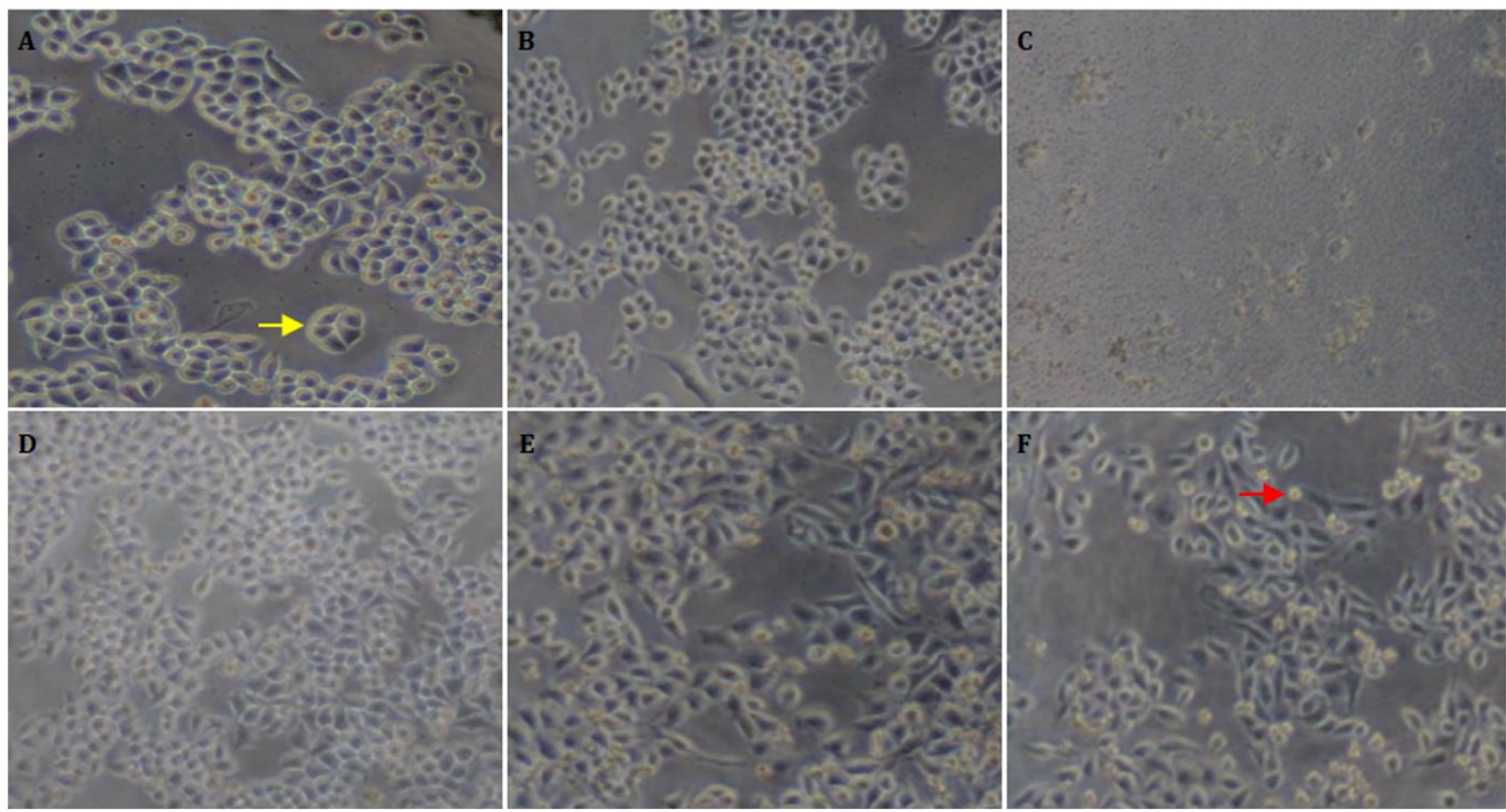

Figure 1. Morphology of WiDr cells after treated with extracts. (A) Control WiDr cells in 24h incubation. (B) Treatment of red ginger extract at $15 \mu \mathrm{g} / \mathrm{mL}$ for $24 \mathrm{~h}$. (C) Treatment of red ginger extract at $500 \mu \mathrm{g} / \mathrm{mL}$ for 24h. (D) Control WiDr cells in $48 \mathrm{~h}$ incubation. (E) Treatment of red ginger extract at $15 \mu \mathrm{g} / \mathrm{mL}$ for $48 \mathrm{~h}$. (F) Treatment of red ginger extract at $500 \mu \mathrm{g} / \mathrm{mL}$ for $48 \mathrm{~h}$. Photographs were taken at 10x magnification. Yellow arrow showed viable cells, while red arrow showed death cells.

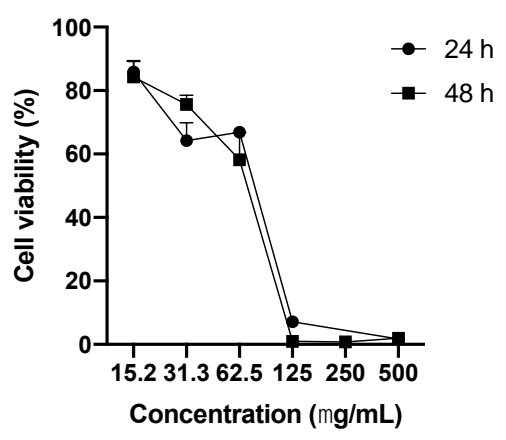

Figure 2. Profile of red ginger extract cytotoxicity on WiDr cells by MTT method. WiDr cells were plated on 96 well-plates then treated with red ginger extract at concentration 15.2, 31.3, 62.5, $125,250,500 \mu \mathrm{g} / \mathrm{mL}$ for incubation 24 and $48 \mathrm{~h}$. Cytotoxicity was expressed by \% cell viability shown as mean \pm SD.

concentration. Treatment of WiDr cells with 5-FU at a concentration of $1000 \mu \mathrm{g} / \mathrm{mL}$ for $24 \mathrm{~h}$ incubation caused cell viability of $70 \%$, which implies that the highest concentration was unable to inhibit cell growth by $50 \%$.

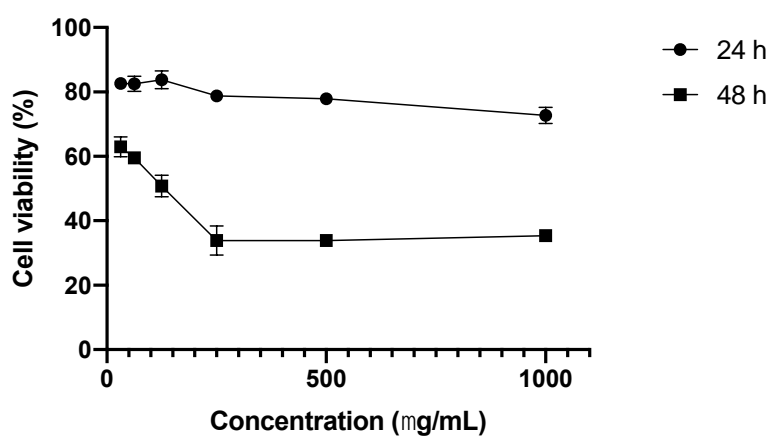

Figure 3. Profile of 5-FU cytotoxicity on WiDr cells by MTT method. WiDr cells were plated on 96 wellplates then treated with 5-FU at concentration 31.3, $62.5,125,250,500,1000 \mu \mathrm{g} / \mathrm{mL}$ for incubation 24 and $48 \mathrm{~h}$. Cytotoxicity was expressed by \% cell viability shown as mean \pm SD.

Furthermore, the incubation of WiDr cells with 5FU at a concentration of $1000 \mu \mathrm{g} / \mathrm{mL}$ for $48 \mathrm{~h}$ produced a cell viability of $35 \%$. The $\mathrm{IC}_{50}$ of $5-\mathrm{FU}$ at $24 \mathrm{~h}$ incubation was undeterminable, while the value at $48 \mathrm{~h}$ incubation was $130 \mu \mathrm{g} / \mathrm{mL}$. 
Combination of Z. officinale var Rubrum extract and 5-FU inhibits WiDr colon cancer cell growth.

The combination treatment of 5-FU with the extract was carried out to determine whether the extract was able to increase the cell growth inhibition compared to the single 5-FU treatment. A $24 \mathrm{~h}$ treatment was carried out to determine the cell viability, with the evaluation carried out using 5-FU at a $1000 \mu \mathrm{g} / \mathrm{mL}$ concentration with varying extract concentration of $8.5,17,25$, and $35 \mu \mathrm{g} / \mathrm{mL}$. The results shown in Figure 4 indicated that the combination of $5-\mathrm{FU} 1000 \mu \mathrm{g} / \mathrm{mL}$ and red ginger extract at 17 and $35 \mu \mathrm{g} / \mathrm{mL}$ was able to suppress cell viability compared to a single treatment. Similarly, the $48 \mathrm{~h}$ combination treatment of 5-FU $60 \mu \mathrm{g} / \mathrm{mL}$ and red ginger extract at $6.3,18.7$, and $25 \mu \mathrm{g} / \mathrm{mL}$ were able to suppress cell viability compared to a single treatment.



Figure 4. Effect combination of 5-FU and red ginger (RG) extract in WiDr cells at 24 hours incubation. Cells were treated 5-FU at concentrations of 1000 $\mu \mathrm{g} / \mathrm{mL}$, and in combination with various values of red ginger extract, such as $8.5,17,25$, and 35 $\mu \mathrm{g} / \mathrm{mL}$. Percentage of cell viability was expressed as mean $\pm \mathrm{SD}$. Statistical analysis used One-way Anova and the Tuckey's range test. ns $=$ not significance, ${ }^{*} \mathrm{p}<0.05,{ }^{* *} \mathrm{p}<0,01$.

Red ginger is a potential agent used to increase the cytotoxic activity of 5-FU in WiDr colon cancer cells. This study evaluated the cytotoxic of red ginger extract, 5-FU, and their combination of WiDr colon cancer cells. The results showed that red ginger extract increases the cytotoxic activity of 5 -FU in WiDr colon cancer cells.

A single treatment of WiDr cells with the extract led to $\mathrm{IC}_{50}$ values of 68 and $65 \mu \mathrm{g} / \mathrm{mL}$ after 24 and $48 \mathrm{~h}$ incubation. This value was not significantly different for both treatment and shows that the extract sufficiently inhibits $50 \%$ growth of WiDr cells at a $65 \mu \mathrm{g} / \mathrm{mL}$ concentration. These data are consistent with the previous research carried out by Ekowati et al. (2012), which indicated that the $\mathrm{IC}_{50}$ value of the same extract was $74 \mu \mathrm{g} / \mathrm{mL}$ after $24 \mathrm{~h}$ treatment on WiDr colon cancer cells.

The use of Z. Officinale var. Roscoe extract on the cytotoxicity evaluation of several colon cancer cells has been reported in numerous studies. Elkady and co-workers (2014) stated that treatment of 116 HCT colon cells with this extract for 24 and $48 \mathrm{~h}$ produced $\mathrm{IC}_{50}$ values of 20 and $25 \mu \mathrm{g} / \mathrm{mL}$, respectively. Hakim et al. (2014) also used the same extract for the treatment of HCT116 , which produced $\mathrm{IC}_{50}$ values of $3 \mathrm{mg} / \mathrm{mL}$ after $72 \mathrm{~h}$. The combination of this extract and Gelam honey modulated the Ras/ERK and PI3K/Akt pathway genes in HT29 colon cancer cells (Tahir et al., 2005).

The treatment of WiDr cells with only 5-FU for 24 and $48 \mathrm{~h}$ created different cell viability values. A $24 \mathrm{~h}$ treatment of 5-FU on WiDr cells did not produce $\mathrm{IC}_{50}$ values because the viability was above $50 \%$, even at the highest concentration. Therefore, the $\mathrm{IC}_{50}$ of 5 -FU for $24 \mathrm{~h}$ incubation time was not determined in this study may due to the resistance of WiDr cells. Zhang et al. (2008) stated that it is widely accepted that the overexpression of thymidylate synthetase is recognized as the main mechanism responsible for 5-FU resistance. Several possibilities can induce thymidylate synthases, such as decreased accumulation of active metabolites, target-associated resistance, and pharmacokinetic. Decreased accumulation of active metabolites due to reduced activation, increased inactivation of 5-FU nucleotides. In addition, WiDr colon cancer cells have molecular characteristics with p53 mutations (Rodrigues et al., 1990). Tumor cells with mutant p53 lack response to apoptotic-inducing agents. Therefore, the combination of 5-FU chemotherapy with red ginger extract is expected to increase the cytotoxic effects of 5-FU.

A combination test was performed to determine whether the extract of $Z$. Officinale var. Rubrum increases the cytotoxicity of the 5-FU. 
The test results showed that the addition of the extract increased cytotoxic activity compared to a single 5-FU treatment. For instance, the treatment of WiDr cells with only 5-FU at a concentration of $1000 \mu \mathrm{g} / \mathrm{mL}$ produced viability of $65 \%$, while a combination of $35 \mu \mathrm{g} / \mathrm{mL}$ of the extract with $1000 \mu \mathrm{g} / \mathrm{mL} 5$-FU produced a viability value of $40 \%$. This combination created a smaller cell viability value compared to every single treatment, and similar to the use of 5-FU at 48-hour incubation. Figure 5 shows that the combination of 5 -FU at a concentration of $60 \mu \mathrm{g} / \mathrm{mL}$ with extract at $25 \mu \mathrm{g} / \mathrm{mL}$ caused a more significant decrease in cell viability compared to a single treatment. This further reinforces that the extract can increase the cytotoxic effect of 5-FU compared to a single administration.

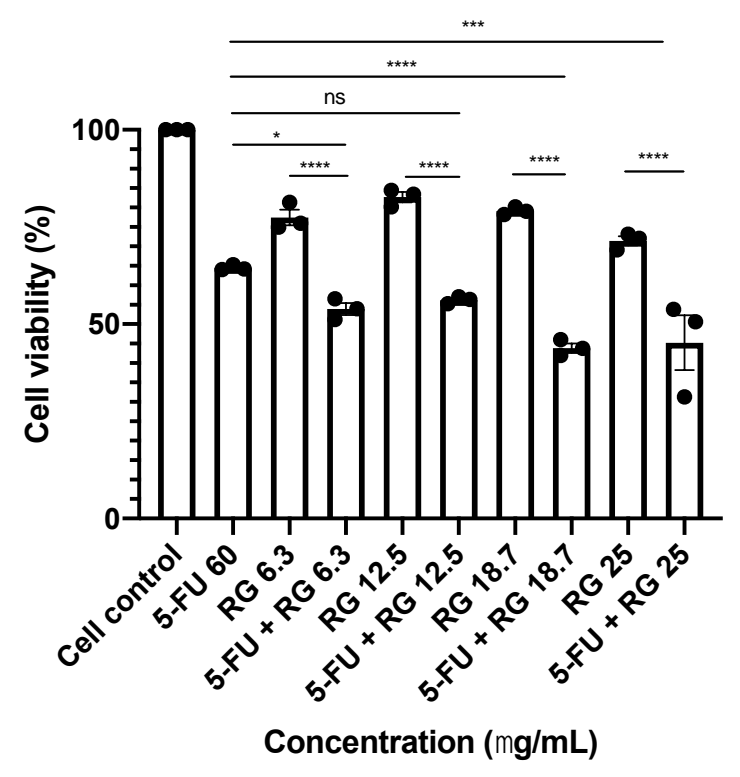

Figure 5. Effect combination of 5-FU and red ginger (RG) extract in WiDr cells at $48 \mathrm{~h}$ incubation. Cells were treated 5-FU at concentrations of $60 \mu \mathrm{g} / \mathrm{mL}$, and in combination with red ginger extract with various values of red ginger extract, such as 6.3, $12.5,18.7$, and $25 \mu \mathrm{g} / \mathrm{mL}$. Percentage of cell viability was expressed as mean \pm SD. Statistical analysis used One-way Anova and the Tuckey's range test. * $\mathrm{p}$ value $<0.05$.

The combination of 5-FU and red ginger extract led to a decrease in viability at all incubation times with a significant difference compared to a single 5-FU treatment. Furthermore, the decrease in cell viability due to the two agents' combined treatment in this study obtained differences in the mechanism of action between red ginger extract and 5-FU on cancer cells. The active ingredients in red ginger are 6-gingerol, 6-shogaol, and zingeron (Ali et al., 2008). 6-shogaol is a dehydrated form of 6-gingerol, and is more pharmacologically attractive because of its higher cytotoxic activity in colon and lung cancer cells (Sang et al., 2009). 6-gingerol induces caspasedependent apoptosis and prevents PMA-induced proliferation in colon cancer by inhibiting MAPK/AP-1 signaling (Radhakrishnan et al., 2014). Pan et al. (2008) stated that 6-shogaol induces apoptosis in colorectal cancer cells through ROS production, caspase activation, and GADD 153 expression. Meanwhile, Qi et al. (2015) stated that 6-shogaol triggers cell cycle arrest in G2/M and can overcome TRAIL resistance in colon cancer through survivin inhibition (Hwang et al., 2015).

$5-\mathrm{FU}$, as a pyrimidine analog acts antagonistically with dUMP to determine the activity of the thymidylate synthetase. Furthermore, 5-FU induces apoptosis through inhibition of DNA synthesis caused by cell deficiency of deoxythymidine triphosphate (dTTP) (Giovannetti et al., 2007). When two test materials with different mechanisms are combined, the obtained results used to reduce cell viability become higher due to increased cancer cell cytotoxicity. Therefore, the combination treatment led to a better decrease in cell viability compared to a single 5-FU treatment.

This is the first study that reveals the potential of red ginger extract in increasing the cytotoxic activity of 5-FU in WiDr colon cancer cells. Previous studies combined 5-FU in WiDr colon cancer cells using the ethyl acetate fraction of Gynura procumbens (Nurulita et al., 2011) and Moringa oleifera leaf extract (Nur et al., 2011). The molecular mechanism by which red ginger extracts increase the cytotoxic activity of 5-FU on colon cancer cells has not be revealed yet, therefore, further research is needed, such as apoptosis assay examination.

In conclusion, red ginger extract increases the cytotoxic activity of 5-FU, therefore it acts as a nutraceutical agent in the treatment of colon cancer.

\section{ACKNOWLEDGMENT}

The authors are grateful to the Ministry of Education and Culture, the Republic of Indonesia, for supporting this research through the Beginner Research Grant 2013 and Competence Based Research Grant 2020. 


\section{REFERENCES}

Ali BH, Blunden G, Tanira MO, Nemmar A. Some phytochemical, pharmacological and toxicological properties of ginger (Zingiber officinale Roscoe): a review of recent research. Food Chem Toxicol. 2008.46(2):409-20.

https://doi.org/10.1016/j.fct.2007.09.085

Ekowati H, Achmad A, Nurrachmani EP, Wasito H, Sri K, Hidayati Z, dkk. Zingiber officinale, Piper retrofractum and Combination Induced Apoptosis and p53 Expression in Myeloma and WiDr Cell Lines. Hayati Journal of Biosciences. 2012.19(3):137-40. https://doi.org/10.4308/hjb.19.3.137

Elkady AI, Hussein RA, Abu-Zinadah OA. Differential control of growth, apoptotic activity and gene expression in human colon cancer cells by extracts derived from medicinal herbs, Rhazya stricta and Zingiber officinale and their combination. World J Gastroenterol. 2014.20(41):15275-88. https://doi.org/10.3748/wjg.v20.i41.1527 5

Fan J, Yang X, Bi Z. 6-Gingerol inhibits osteosarcoma cell proliferation through apoptosis and AMPK activation. Tumour Biol. 2015.36(2):1135-41.

https://doi.org/10.1007/s13277-0142723-1

Ferlay J, Colombet M, Soerjomataram I, Mathers C, Parkin DM, Piñeros M, Znaor A, Bray F. Estimating the global cancer incidence and mortality in 2018: GLOBOCAN sources and methods. Int J Cancer. 2019;144(8):194153. https://doi.org/10.1002/ijc.31937.

Giovannetti E, Backus HHJ, Wouters D, Ferreira CG, van Houten VMM, Brakenhoff dkk. Changes in the Status of p53 Affect Drug Sensitivity to Thymidylate Synthase (TS) Inhibitors by Altering TS Levels, Br J Can. 2007.96:769-75. https://doi.org/10.1038/sj.bjc.6603639

Hakim L, Alias E, Makpol S, Ngah WZ, Morad NA, Yusof YA. Gelam honey and ginger potentiate the anti cancer effect of 5-FU against HCT 116 colorectal cancer cells. Asian Pac J Cancer Prev. 2014.15(11):4651-7. https://doi.org/10.7314/APJCP.2014.15.11 .4651

Han MA, Woo SM, Min KJ, Kim S, Park JW, Kim DE, dkk. 6-Shogaol enhances renal carcinoma Caki cells to TRAIL-induced apoptosis through reactive oxygen species-mediated cytochrome c release and down-regulation of c-FLIP(L) expression. Chem Biol Interact. 2015.228:69-78.

https://doi.org/10.1016/j.cbi.2015.01.020

Hsu YL, Hung JY, Tsai YM, Tsai EM, Huang MS, Hou MF, dkk. 6-shogaol, an active constituent of dietary ginger, impairs cancer development and lung metastasis by inhibiting the secretion of CC-chemokine ligand 2 (CCL2) in tumor-associated dendritic cells. J Agric Food Chem. 2015.63(6):1730-8. https://doi.org/10.1021/jf504934m

Hwang JS, Lee HC, Oh SC, Lee DH, Kwon KH. Shogaol overcomes TRAIL resistance in colon cancer cells via inhibiting of survivin. Tumour Biol. $2015 . \quad$ Jun 11:1-11. https://doi.org/10.1007/s13277-0153629-2

Kim MO, Lee MH, Oi N, Kim SH, Bae KB, Huang Z, dkk. [6]-shogaol inhibits growth and induces apoptosis of non-small cell lung cancer cells by directly regulating Akt1/2. Carcinogenesis. 2014.35(3):683-91. https://doi.org/10.1093/carcin/bgt365

Longley DB, Harkin DP, Johnston PG. 5-fluorouracil: mechanisms of action and clinical strategies. Nat Rev Cancer. 2003.3(5):330-8. https://doi.org/10.1038/nrc1074

Meyerhardt JA, Mayer RJ. Systemic Therapy for Colorectal Cancer. N. Engl. J. Med. 2005.352(5): 476-487. https://doi.org/10.1056/NEJMra040958

Nur KA, Putri H, Cahyani FM, Katarina A, Susidarti RA, Meiyanto E. Ethanolic extract of Moringa oleifera L., Increases Sensitivity of WiDr colon cancer line towards 5-Fluorouracil. Indonesian Journal of Cancer Chemoprevention. 2011.1(2):124-8. http://dx.doi.org/10.14499/indonesianjcan chemoprev1iss2pp124-128

Nurulita NA, Meiyanto E, Sugiyanto, Matsuda E, Kawaichi M. The Ethyl Acetate Fraction of Gynura procumbens Sensitizes WiDr Colon Cancer Cell Line Against 5-Fluorouracil But Shows Antagonism With Cisplatin. International Journal of Phytomedicine. 2011.3(3):392-405.

Pan MH, Hsieh MC, Kuo JM, Lai CS, Wu H, Sang S, dkk. 6-Shogaol induces apoptosis in human colorectal carcinoma cells via ROS production, caspase activation, and GADD 153 expression. Mol Nutr Food Res. 2008.52(5):527-37.

https://doi.org/10.1002/mnfr.200700157 
Prasad S, Tyagi AK. Ginger and its constituents: role in prevention and treatment of gastrointestinal cancer. Gastroenterol Res Pract. 2015.2015:142979. https://doi.org/10.1155/2015/142979

Qi LW, Zhang Z, Zhang CF, Anderson S, Liu Q, Yuan CS, dkk. Anti-Colon Cancer Effects of 6Shogaol Through G2/M Cell Cycle Arrest by p53/p21-cdc2/cdc25A Crosstalk. Am J Chin Med.

2015:1-14. https://doi.org/10.1142/S0192415X15500 469

Radhakrishnan EK, Bava SV, Narayanan SS, Nath LR, Thulasidasan AK, Soniya EV, dkk. [6]Gingerol induces caspase-dependent apoptosis and prevents PMA-induced proliferation in colon cancer cells by inhibiting MAPK/AP-1 signaling. PLoS One. 2014.9(8):e104401. https://doi.org/10.1371/journal.pone.0104 401

Rodrigues NR, Rowan A, Smith ME, Kerr IB, Bodmer WF, Gannon JV, dkk. p53 mutations in colorectal cancer. Proc Natl Acad Sci USA. 1990. 87(19):7555-9. https://doi.org/10.1073/pnas.87.19.7555

Saif MW, Choma A, Salamone SJ, Chu E. Pharmacokinetically guided dose adjustment of 5-fluorouracil: a rational approach to improving therapeutic outcomes. J Natl Cancer Inst. 2009.
101(22):1543-52.

https://doi.org/10.1093/jnci/djp328

Sang S, Hong J, Wu H, Liu J, Yang CS, Pan MH, dkk. Increased growth inhibitory effects on human cancer cells and anti-inflammatory potency of shogaols from Zingiber officinale relative to gingerols. J Agric Food Chem. 2009.57(22):10645-50. https://doi.org/10.1021/jf9027443

Tahir AA, Sani NF, Murad NA, Makpol S, Ngah WZ, Yusof YA. Combined ginger extract and Gelam honey modulate Ras/ERK and PI3K/AKT pathway genes in colon cancer HT29 cells. Nutr J. 2015.14:31. https://doi.org/10.1186/s12937-0150015-2

Wahyuni S, Xu DH, Bermawie N, Tsunematsu H, Ban $\mathrm{T}$, Genetic relationships among ginger accessions based on AFLP marker, Jurnal Bioteknologi Pertanian, 2003. 8(2): 60-68

Wu JJ, Omar HA, Lee YR, Teng YN, Chen PS, Chen YC, dkk. 6-Shogaol induces cell cycle arrest and apoptosis in human hepatoma cells through pleiotropic mechanisms. Eur J Pharmacol. 2015.762:449-458.

https://doi.org/10.1016/j.ejphar.2015.06.0 32

Zhang N, Yin Y, Xu SJ, Chen WS, 5-Fluorouracil: Mechanisms of Resistance and Reversal Strategies. Molecules. 2008.13:1551-96. https://doi.org/10.3390/molecules130815 51 